NOTE

\title{
Epizootic ulcerative syndrome caused by Aphanomyces invadans in captive bullseye snakehead Channa marulius collected from south Florida, USA
}

\author{
Ryan K. Saylor ${ }^{1}$, Debra L. Miller ${ }^{2, *}$, Mark W. Vandersea ${ }^{3}$, Mark S. Bevelhimer ${ }^{4}$, \\ Pamela J. Schofield ${ }^{5}$, Wayne A. Bennett ${ }^{1}$ \\ ${ }^{1}$ Department of Biology, University of West Florida, 11000 University Parkway, Pensacola, Florida 32514, USA \\ ${ }^{2}$ Veterinary Diagnostic and Investigational Laboratory, University of Georgia, 43 Brighton Road, Tifton, \\ Georgia 31793-1389, USA \\ ${ }^{3}$ National Ocean Service, National Oceanic and Atmospheric Administration, 101 Pivers Island Road, Beaufort, \\ North Carolina 28516, USA \\ ${ }^{4}$ Oak Ridge National Laboratory, Environmental Sciences Division, PO Box 2008, Oak Ridge, Tennessee 37831-6351, USA \\ ${ }^{5}$ US Geological Survey, 7920 NW 71st Street, Gainesville, Florida 32653, USA
}

\begin{abstract}
Epizootic ulcerative syndrome (EUS) caused by the oomycete Aphanomyces invadans is an invasive, opportunistic disease of both freshwater and estuarine fishes. Originally documented as the cause of mycotic granulomatosis of ornamental fishes in Japan and as the cause of EUS of fishes in southeast Asia and Australia, this pathogen is also present in estuaries and freshwater bodies of the Atlantic and gulf coasts of the USA. We describe a mass mortality event of 343 captive juvenile bullseye snakehead Channa marulius collected from freshwater canals in Miami-Dade County, Florida. Clinical signs appeared within the first $2 \mathrm{~d}$ of captivity and included petechiae, ulceration, erratic swimming, and inappetence. Histological examination revealed hyphae invading from the skin lesions deep into the musculature and internal organs. Species identification was confirmed using a species-specific PCR assay. Despite therapeutic attempts, 100\% mortality occurred. This represents the first documented case of EUS in bullseye snakehead fish collected from waters in the USA. Future investigation of the distribution and prevalence of $A$. invadans within the bullseye snakehead range in south Florida may give insight into this pathogen-host system.
\end{abstract}

KEY WORDS: Epizootic ulcerative syndrome $\cdot$ Mycotic dermatitis $\cdot$ Mycotic myositis $\cdot$ Non-native fish species $\cdot$ Oomycete $\cdot$ Water mold

\section{INTRODUCTION}

Epizootic ulcerative syndrome (EUS) has caused substantial economic losses to the aquaculture industry in countries such as Thailand and Bangladesh (Lilley et al. 1998). The etiology for this disease may involve multiple pathogens; however, most consistently, Aphanomyces invadans (Family: Leptolegni- aceae) has been isolated from lesioned fishes in the USA (Blazer et al. 1999, 2002, Vandersea et al. 2006, Sosa et al. 2007b). A. invadans is an oomycete that is widespread in distribution and has been linked with cases of EUS since it was first documented in Japan in 1971 (Chinabut 1998, Lilley et al. 1998). While most severe cases of EUS in southeast Asia and Australia are reported from aquaculture facilities, those in the USA 
are almost exclusively reported from wild-caught fishes (Dykstra et al. 1989, Noga et al. 1991, Blazer et al. 1999). In 1984, the first confirmed cases of EUS in the USA were documented in Atlantic menhaden Brevoortia tyrannus from estuaries of North Carolina (Dykstra et al. 1986). Since 1984, fish exhibiting ulcerative lesions typical of $A$. invadans infection have been documented in estuaries and rivers of the Atlantic coast from Long Island to Florida (Blazer et al. 2002, Hawke et al. 2003). Most recently, Sosa et al. (2007b) documented $A$. invadans infection of 21 species of fish collected from estuarine and freshwater systems throughout Florida.

Aphanomyces invadans is an opportunistic pathogen that can be highly invasive, gaining entry through surface wounds or an otherwise compromised mucus barrier. In challenge studies, mortality associated with EUS is high and may approach $100 \%$ (Kiryu et al. 2003, Johnson et al. 2004, Sosa et al. 2007a). Cases of EUS in snakeheads (Family: Channidae) have previously been documented in southeast Asia (Lilley et al. 1998). Treatment is only applicable to captive animals and often has limited success because some antifungal agents (e.g. malachite green and formalin) are toxic to the fish or do not penetrate the body deeply enough to reach the pathogen, which invades deep into the muscle tissue and internal organs (Campbell et al. 2001).

Snakeheads are a group of freshwater, air-breathing fish, consisting of approximately 30 species in 2 genera, Channa and Parachanna. The former is found predominantly in eastern Asia as far south as Vietnam and as far north as Russia, while the latter is found only in subtropical Africa (Courtenay \& Williams 2004). Snakeheads are opportunistic carnivores that exhibit parental care (i.e. guarding their eggs and fry) and can tolerate very poor water quality for extended periods of time. These traits contribute to making snakeheads a desirable aquaculture species, but potentially harmful if introduced into naïve environments. Because they are air-breathers, they are often shipped and sold alive, potentiating the likelihood of intentional or accidental introduction to non-native environments (Fuller et al. 1999, Courtenay \& Williams 2004). In the USA, snakeheads have been found within freshwater bodies since the early 1900s (Fuller et al. 1999, Courtenay \& Williams 2004). Currently, 4 species of snakeheads may be found in the USA: blotched snakehead C. maculata; striped snakehead C. striata; northern snakehead $C$. argus; and bullseye snakehead $C$. marulius. Of these, only the northern and bullseye snakeheads are found within the continental USA. The first established northern snakehead population was initially documented in Crofton, Maryland during the summer of 2002, but the species has since become established in the Potomac River along Virginia and Maryland
(Courtenay \& Williams 2004, Odenkirk \& Owens 2005, US Geological Survey 2009). The bullseye snakehead was documented in freshwater canals of Tamarac, Florida during the summer of 2000 and has remained relatively localized to specific canal systems (Courtenay \& Williams 2004, Shafland et al. 2008). Herein we report the first known mass mortality event caused by EUS in bullseye snakehead collected from freshwater canals of south Florida.

\section{MATERIALS AND METHODS}

Animal collection and husbandry. In June 2008, 343 juvenile bullseye snakeheads were collected by boat electrofishing from the C-14 canal system at Donaldson Park $\left(26^{\circ} 14.485^{\prime} \mathrm{N}, 80^{\circ} 10.827^{\prime} \mathrm{W}\right)$ and Winfield Boulevard $\left(26^{\circ} 15.486^{\prime} \mathrm{N}, 80^{\circ} 12.643^{\prime} \mathrm{W}\right)$ in south Florida by Florida Fish and Wildlife Conservation Commission (FWC) biologists. Fish were placed into captivity at the University of West Florida (UWF), Pensacola as part of an investigation of the thermal physiology of this non-native species. Snakeheads were transported to UWF in a dual-hulled, fiberglass-reinforced, 22501 tank (Model SST-150, Red Ewald). The tank was filled with pond water found adjacent to the Non-native Fish Research Laboratory in Boca Raton, Florida. After $24 \mathrm{~h}$, the fish were equally distributed into twenty-eight $64 \mathrm{l}$ plastic aquaria containing dechlorinated tap water, within an Environmental Growth Chamber ${ }^{\circledR}$ (EGC, Chagrin Falls) set at $20 \pm$ $0.1^{\circ} \mathrm{C}$. Individual tank temperatures were maintained at $31 \pm 0.8^{\circ} \mathrm{C}$ using Ebo-Jägger submersible heaters (EHEIM, Deizisau, Germany), and filtration was provided by corner filters containing activated charcoal. The photoperiod was controlled at $12 \mathrm{~h}$ light: $12 \mathrm{~h}$ darkness. Each tank contained artificial cover composed of curling ribbon tied onto corrugated plastic and held in place by small lead weights. Fish were fed every $3 \mathrm{~d}$. At each feeding, they were offered live, wild-caught western mosquito fish Gambusia affinis, until they accepted frozen beef heart and liver (which took $\sim 1 \mathrm{mo}$ ). Water quality, including $\mathrm{NH}_{3}, \mathrm{NO}_{2}^{-}, \mathrm{NO}_{3}{ }^{-}$, $\mathrm{pH}$, and temperature, was monitored daily and a $25 \%$ water change was performed on all tanks weekly or as dictated by water quality parameters.

Tissue collection. Approximately 7 wk post-capture and at the time of peak mortalities, 4 fish were euthanized by transdermal exposure to a mixture of 1:9 clove oil:ethanol diluted to $200 \mathrm{mg} \mathrm{l}^{-1}$ in water (Hartman 2006; protocol approved by the UWF Institutional Animal Care and Use Committee [IACUC]) and were shipped overnight on ice to the University of Georgia Veterinary Diagnostic and Investigational Laboratory, Tifton for diagnostic evaluation. Fish were euthanized 
prior to shipment because live injurious species could not be transported across state lines (Lacey Act 16 U.S.C. SS 3371-3378). Euthanasia was performed on select individuals just prior to shipment to ensure minimal postmortem change.

Necropsies were performed on the 4 fish. In brief, a ventral midline incision was made and internal organs examined for lesions. A subset of each tissue (brain, skin [especially lesions], skeletal muscle, eye, thymus, heart, gill, spleen, intestine, kidney, liver) was preserved in $10 \%$ buffered formalin for histological analysis. Formalin-fixed tissues were routinely processed using a Shandon Pathcentre ${ }^{\circledR}$ tissue processor (Thermo Scientific) and embedded in paraffin. One or more $4 \mu \mathrm{m}$ thick sections were cut from each paraffin block and placed on glass slides. The slides were stained with hematoxylin and eosin (H\&E), cover-slipped, and viewed by light microscopy (Olympus BX41) for histopathological changes. Photomicrographs of the stained slide preparations were taken using an Olympus DP70 camera attached to the light microscope. To examine for fungal elements, a Grocott-Gomori's methenamine silver stain was applied following Carson (1997). Fungal hyphae were measured using an ocular micrometer housed in the light microscope.

At necropsy an additional subset of select tissues (liver, kidney, intestine, skin) was collected for virus isolation and bacterial culture. Fresh tissue samples were processed for bacterial culture and viral testing. For bacterial culture, tissues were inoculated into $5 \%$ sheep blood and MacConkey agar (Remel, Fisher Scientific) and incubated at $27^{\circ} \mathrm{C}$. Bacterial isolates were identified either by using an automated identification system (Sensititer, Trek Diagnostic Systems) or conventional biochemical testing. For virus isolation, fresh tissue specimens from all organs were used. A 10\% tissue homogenate was made and filtered directly onto confluent monolayers of fathead minnow cells, channel catfish ovary, epithelioma papulosum cyprinid, and white sturgeon skin. Cell monolayers were examined daily for $2 \mathrm{wk}$ and if negative, a second passage was performed to confirm.

PCR. PCR was used for molecular analysis of the tissues. Genomic DNA (gDNA) was extracted from paraffin-embedded tissues, from each of the 4 fish, following the protocol of Kattenbelt et al. (2000). Paraffinembedded tissues included sections identified by histology to contain hyphae (i.e. skin and skeletal muscle lesions) and 2 gDNA samples were obtained for each fish. Approximately $50 \mathrm{ng}$ of purified gDNA was added to the PCR reaction mixtures and the fish tissues were PCR-assayed using the methods described in Vandersea et al. (2006). The PCR assay included a positive and negative control. The positive control incorporated $50 \mathrm{ng}$ of Aphanomyces invadans gDNA in the reaction mixture. The negative control substituted $1 \times \mathrm{PCR}$ reaction buffer for DNA in the reaction mixture to confirm that the reagents were not contaminated. The Ainvad2F (5' -TCA TTG TGA GTG AAA CGG TG-3') and Ainvad-ITSR1 (5'-GGC TAA GGT TTC AGT ATG TAG-3') primers were used to amplify a species-specific $234 \mathrm{bp}$ product. An aliquot ( $5 \mu \mathrm{l}$ ) from each amplification was analyzed by agarose gel electrophoresis on a 3.5\% Tris-acetate-EDTA (TAE) gel using $75 \mathrm{~V}$ of current and ethidium bromide staining. Digital gel images were captured using an Alpha Innotech MultiImage ${ }^{\mathrm{TM}}$ Light Cabinet and UV illumination. The size of the PCR product was estimated by comparison with a Mark IX molecular weight ladder (Roche Diagnostics).

Treatment. Although therapeutic treatments were attempted once fish started dying, more aggressive treatments were given once a diagnosis of Aphanomyces invadans was established. Treatments included increasing the frequency of feedings, lowering the water temperature, and various chemical treatments of water baths and dips (see Table 1). To attempt to control aggression in the fish, the feeding frequency was increased from every $3 \mathrm{~d}$ to every $2 \mathrm{~d}$ and the water temperature lowered to $24 \pm 0.5^{\circ} \mathrm{C}$. Water baths included over-the-counter antibacterial treatments such as nitrofurazone and furazolidone (Furan- $2^{\circledR}$, Aquarium Pharmaceuticals, Mars Fishcare) or antifungal treatments, including a herbal remedy (IchAttack ${ }^{\circledR}$, Kordon), Victoria (malachite) green and acriflavine (Fungus Cure ${ }^{\circledR}$, Aquarium Pharmaceuticals, Mars Fishcare), and a $0.0038 \%$ solution of malachite green (Kordon), which were administered according to the respective manufacturer's recommendations. A water bath consisting of $1 \mathrm{mg} \mathrm{l}^{-1}$ malachite green with $20 \mathrm{mg} \mathrm{l}^{-1}$ formalin also was used (Clifton-Hadley \& Alderman 1987). Water baths were repeated daily for 3 to $10 \mathrm{~d}$ except Fungus Cure ${ }^{\circledR}$, which was administered every other day. Water dips, rather than baths, were used to treat fish with $\mathrm{NaCl}$, formalin, and hydrogen peroxide, as these chemicals may be toxic to some fishes (Mashima \& Lewbart 2000). Betadine wipes (10\% iodine solution) used over the skin lesions followed by a freshwater rinse were also attempted. Evaluation of the effectiveness of the treatments was subjective based on resolution of lesions and whether the fish survived.

\section{RESULTS AND DISCUSSION}

Clinical signs were initially observed in 2 tanks on Day 2 of captivity, and appeared in other tanks at a rate of approximately 5 to 7 tanks $\mathrm{wk}^{-1}$, with fish from all tanks showing clinical signs by Day 34. Mortality began 10 d after captivity on 30 June 2008 and peaked 
at 24 fish $\mathrm{d}^{-1}$ after $7 \mathrm{wk}$ (Day 55) of captivity. The first clinical sign observed was petechia and ecchymosis on the dorsal, anal, and caudal fin rays. Subsequent subscale swelling occurred after 7 to $9 \mathrm{~d}$, and was especially prominent in the nape and opercular regions of the head (Fig. 1A). Affected areas of the nape were often darker than the surrounding tissue. Muscle wasting, ocular opacity, and cotton-like tufts also were noted generally $10 \mathrm{~d}$ after the onset of clinical signs. By $15 \mathrm{~d}$ post-onset of clinical signs, ulceration and depigmentation occurred. Behavioral changes included erratic swimming and rubbing along surfaces, with rubbing often noted just before the onset of poor health, but then eventually progressing to a loss of equilibrium and an inability to feed in terminal stages. Additionally, tank-mate aggression gradually decreased as the signs of infection increased in number or worsened. Increased respiratory effort and airbreathing were noted in the terminal stages, with death occurring 24 to $48 \mathrm{~h}$ later.
At necropsy, petechia, ulceration, and muscle wasting were noted. Histological sections of skin from multiple areas, especially the head region, had exuberant hyphae invading through the ulcerated skin, into the skeletal muscle (Fig. 1B) and to a lesser extent into other organs including the kidney (Fig. 1C) and nerves. Corneas were generally swollen by edema, and hyphae were present, primarily in the periocular area but also occasionally in the cornea (Fig. 1D). In more severely affected areas, granulomatous inflammation was also present, and was characterized by numerous macrophages, few lymphocytes and eosinophils, and scant cellular debris. Hyphae were nonseptate with irregular walls and occasional branches and varied in width (10 to $20 \mu \mathrm{m}$ ). The surrounding muscle fibers were fragmented, vacuolated, and disrupted with loss of cross striations and separation of the fibers. These gross and histological changes were consistent with ulcerative dermatitis and myositis. The PCR products generated from the tissue samples (which included the skin and
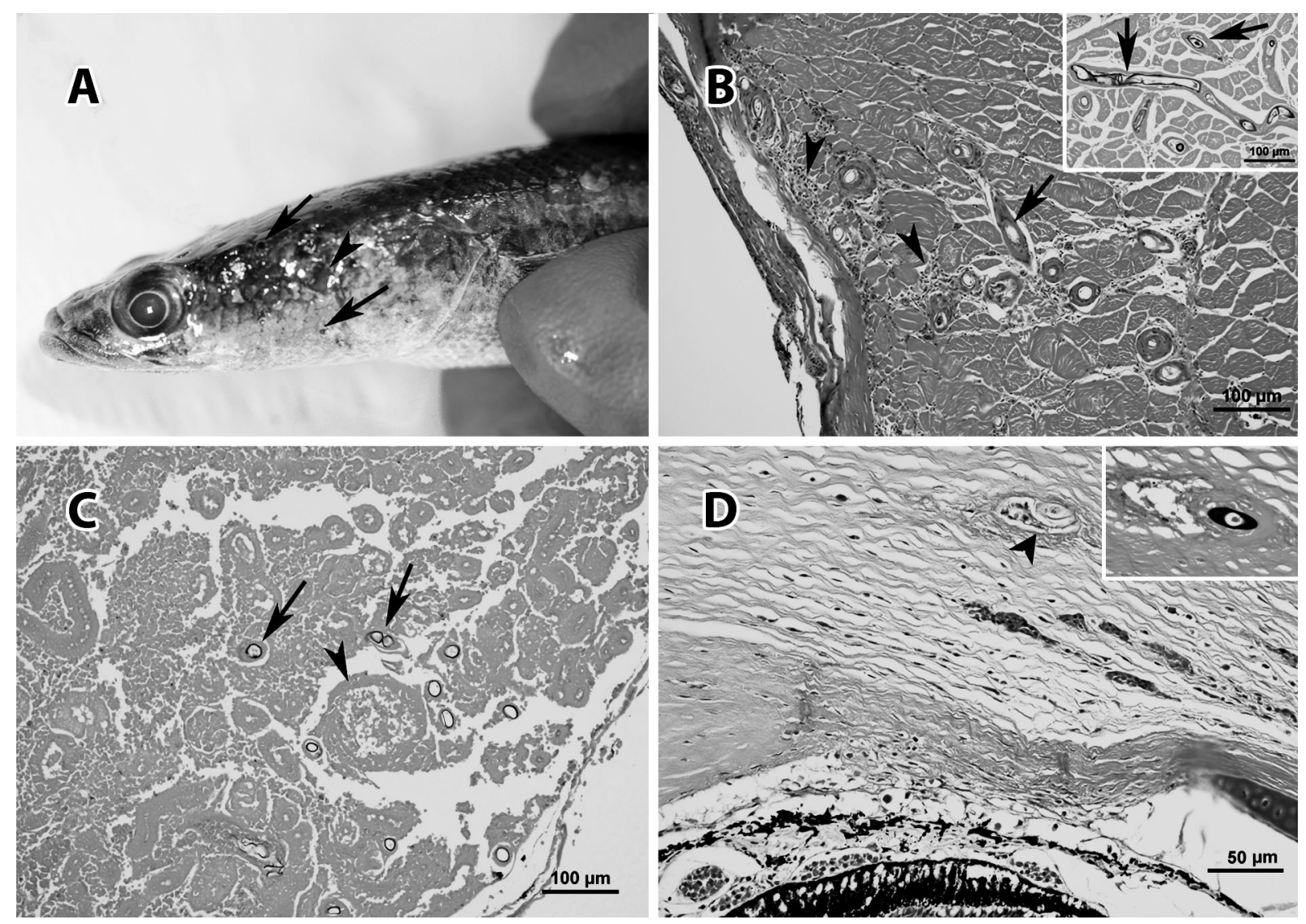

Fig. 1. Channa marulius infected with Aphanomyces invadans. (A) Snakehead juvenile with petechiation (arrows) and ulceration (arrowhead). (B) H\&E-stained section showing hyphae (arrow) invading through the skeletal muscle with granulomatous inflammation (arrowheads) that was characterized by macrophages, lymphocytes, and eosinophils. Inset is a Grocott-Gomori's methenamine silver stain of the same section that more clearly shows the hyphae (arrows). (C) Grocott-Gomori's methenamine silver-stained section of kidney showing hyphae (arrows); a glomerulus is noted (arrowhead) for orientation. (D) H\&E-stained section of an eye showing a hyphal element (arrowhead) in the cornea. Inset is a Grocott-Gomori's methenamine silver stain highlighting the hyphalal element in the cornea 
skeletal muscle lesions) were indicative of the presence of Aphanomyces invadans in all 4 fish (Fig. 2).

Results of other tests were either negative or incidental findings. Virus isolation was negative. Bacterial culture revealed opportunistic organisms in multiple organs (liver, kidney, intestine, skin) of all fish, and included Aeromonas hydrophila, A. sobria, Citrobacter freundii, Pseudomonas mendocina, P. fluorescens, Edwardsiella tarda, Streptococcus-alpha hemolytic, Chryseobacterium meningosepticum, Stenotrophomonas maltophilia, and Plesiomonas shigelloides. Given the lack of corresponding histological changes (e.g. presence of intracellular bacteria) to these organs (especially the liver and kidney) and the fact that the fish had been dead $>24 \mathrm{~h}$ before tissue collection, these bacteria were interpreted as either postmortem growth or incidental (i.e. rather than bacterial septicemia). Other findings included rare numbers of trematode and cestode cysts within the coelomic cavity but not invading organs (noted histologically), and rare numbers of nematodes free in the body cavity (noted grossly). These parasites are commonly observed in free-ranging lower vertebrates, and as none of the parasites in these fish were invading organs, they were interpreted as incidental.

At the time the diagnosis of Aphanomyces invadans was made ( $60 \mathrm{~d}$ post-capture), $<50 \%$ of the fish remained alive and more aggressive treatments were attempted. Treatments included attempts to reduce stress (e.g. associated with tank mate aggression or water quality) and chemotherapy. Juvenile snakeheads can be very aggressive and larger juveniles would target the smallest fish in each tank. The poste-

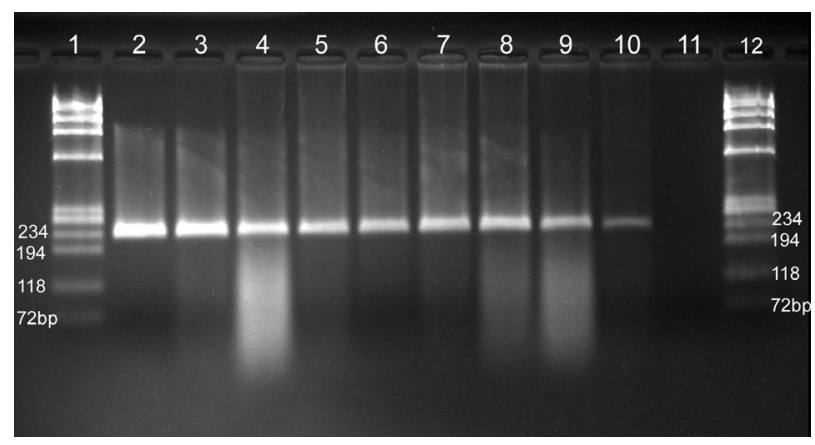

Fig. 2. Gel electrophoresis of the Aphanomyces invadans PCR assay of samples collected from 4 lesioned (2 samples per fish) Channa marulius. Lanes 1 and 12: Mark IX molecular weight ladder (Roche Diagnostics); Lane 2: A. invadans positive control that incorporated $50 \mathrm{ng}$ of $A$. invadans gDNA in the reaction mixture (234 bp); Lanes 3 to 10: bullseye snakehead tissue samples; Lane 11: negative control that substituted 1× PCR reaction buffer for DNA in the reaction mixture. The image was captured using a MultiImage ${ }^{\mathrm{TM}}$ Light Cabinet (Alpha Innotech) and UV illumination rior edges of the dorsal, anal, and caudal fins, or opercular regions on the head were bitten with the highest frequency and were often the locations for the initial lesions, and likely served as sites of entry for $A$. invadans. Fairweather (1999) observed similar aggressive behavior in Channa striata and noted that areas (dorsal, anal, caudal fins) most frequently attacked by other fish became the initial site of $A$. invadans infection. To attempt to address the aggressive behavior, fish were fed more frequently (every other day) and tank temperatures were dropped to $24 \pm 0.5^{\circ} \mathrm{C}$.

Chemotherapy included a combination of water baths ( $<24$ h exposure), water dips ( $<15$ min exposure), and chemical wipes (Stoskopf 1993, Mashima \& Lewbart 2000) (Table 1). Treatments had minimal efficacy, presumably due to their inability to reach the deeply penetrating Aphanomyces invadans hyphae (see Campbell et al. 2001). Despite our attempts at treatment, $100 \%$ mortality occurred by 2.5 mo (73 d) postcapture (Fig. 3).

Many factors likely contributed to this epizootic, including capture stress, lack of prophylactic treatment (e.g. low-dose saltwater bath), and shipment of fish in water collected from a local pond known to contain high densities of fishes. Husbandry factors that potentially contributed to this epizootic include maintaining fish in pond water for $24 \mathrm{~h}$ (during the acclimation period), using wild-caught mosquito fish as a food source, and inadequate sterilization of equipment used to monitor water quality and to perform water changes. Although Aphanomyces invadans infection in mosquito fish was not noted, it is possible that secondary zoospores may have been mechanically transported on these fish (Kiryu et al. 2003), and therefore, should be considered as a source of the pathogen. Similarly, Fairweather (1999) documented that contamination of tank equipment was the likely cause for control-group fish exhibiting signs of EUS. Finally, dropping the tank temperature to $24^{\circ} \mathrm{C}$ may have helped control aggressive behavior in the fish, but it also may have provided a more (i.e. compared to $31^{\circ} \mathrm{C}$ ) optimal temperature for $A$. invadans growth because the lower temperature is in the middle of the optimal range $\left(19\right.$ to $\left.30^{\circ} \mathrm{C}\right)$ for $A$. invadans growth (Lilley \& Roberts 1997, Lilley et al. 1998).

Introduction of non-native species can have deleterious impacts on native species, through predation, competition for resources, hybridization, or the introduction of novel pathogens (Courtenay 2007). For example, Kiesecker et al. (2001) found that introduced salmonids became a vector for Saprolegnia spp. to naïve western toad Bufo boreas embryos. Aphanomyces invadans may disseminate similarly. Many factors play a role in how a pathogen might affect a fish population and include ability to infect a host, duration 
Table 1. Chemotherapies used in an attempt to control epizootic ulcerative syndrome caused by Aphanomyces invadans in juvenile Channa marulius. P: primary infection with $A$. invadans; S: secondary fungal or bacterial infections; na: not applicable

\begin{tabular}{|c|c|c|c|c|}
\hline Treatment & Active chemical & Dosage & Duration & Response $^{a}$ \\
\hline Water bath & $0.0038 \%$ malachite green ${ }^{b}$ & $0.132 \mathrm{ml} \mathrm{l}^{-1}(\mathrm{v} / \mathrm{v})$ & $\begin{array}{l}10 \mathrm{~d} \\
\text { (once daily) }\end{array}$ & $\begin{array}{l}\text { P: not effective } \\
\text { S: fungal only }\end{array}$ \\
\hline Water dip & $\begin{array}{l}3 \mathrm{ppt} \mathrm{NaCl} \\
250 \mathrm{ppm} \text { formalin }\end{array}$ & $\begin{array}{l}45 \mathrm{~g} \mathrm{NaCl} \\
4 \mathrm{ml} 10 \% \text { formalin }\end{array}$ & $30 \mathrm{~min}$ & $\begin{array}{l}\text { P: not effective } \\
\text { S: fungal only }\end{array}$ \\
\hline Water dip & $\begin{array}{l}22 \mathrm{ppt} \mathrm{NaCl} \\
250 \mathrm{ppm} \mathrm{formalin}^{\mathrm{c}}\end{array}$ & $\begin{array}{l}330 \mathrm{~g} \mathrm{NaCl} \\
4 \mathrm{ml} 10 \% \text { formalin }\end{array}$ & $10 \mathrm{~min}$ & $\begin{array}{l}\text { na; could not } \\
\text { tolerate exposure }\end{array}$ \\
\hline $\begin{array}{l}\text { Water bath } \\
\text { Ich-Attack }{ }^{\circledR b}\end{array}$ & $\sim 5 \%$ praziquantel & $0.066 \mathrm{ml} \mathrm{l}^{-1}$ & $\begin{array}{l}5 \mathrm{~d} \\
\text { (once daily) }\end{array}$ & Not effective \\
\hline $\begin{array}{l}\text { Water bath } \\
\text { Furan- } 2^{\circledR d}\end{array}$ & $\begin{array}{l}\text { Nitrofurazone } \\
\text { Furazolidone }\end{array}$ & $\begin{array}{l}1.58 \mathrm{ppm} \\
0.66 \mathrm{ppm}\end{array}$ & $\begin{array}{l}4 \mathrm{~d} \\
\text { (once daily) }\end{array}$ & Not effective \\
\hline Water dip & $3 \%$ hydrogen peroxide & $17.5 \mathrm{ml} \mathrm{l}^{-1}$ & $10 \min$ & $\begin{array}{l}\text { Not effective, toxic } \\
\text { in late stages }\end{array}$ \\
\hline Wipe & $\begin{array}{l}\text { Betadine }^{\circledR f} \\
10 \% \text { iodine tincture }\end{array}$ & Wipe affected area & $\begin{array}{l}\text { Wipe and } \\
\text { immediate rinse }\end{array}$ & $\begin{array}{l}\text { P: not effective } \\
\text { S: fungal only }\end{array}$ \\
\hline $\begin{array}{l}\text { Water bath } \\
\text { Fungus Cure }{ }^{\circledR \mathrm{d}}\end{array}$ & $\begin{array}{l}\text { Victoria (malachite) green } \\
\text { Acriflavin }\end{array}$ & $\begin{array}{l}0.080 \mathrm{ppm} \\
0.800 \mathrm{ppm}\end{array}$ & $\begin{array}{l}4 \mathrm{~d} \\
\text { (every other day) }\end{array}$ & $\begin{array}{l}\text { P: not effective } \\
\text { S: fungal only }\end{array}$ \\
\hline Water bath & $\begin{array}{l}0.1 \mathrm{ppm} \text { malachite green } \\
20 \mathrm{ppm} \text { formalin }{ }^{\mathrm{g}}\end{array}$ & $\begin{array}{l}5.7 \mathrm{mg} \text { malachite green } \\
1.2 \mathrm{ml} 10 \% \text { formalin }\end{array}$ & $\begin{array}{l}3 \mathrm{~d} \\
\text { (once daily) }\end{array}$ & Not effective \\
\hline \multicolumn{5}{|c|}{ 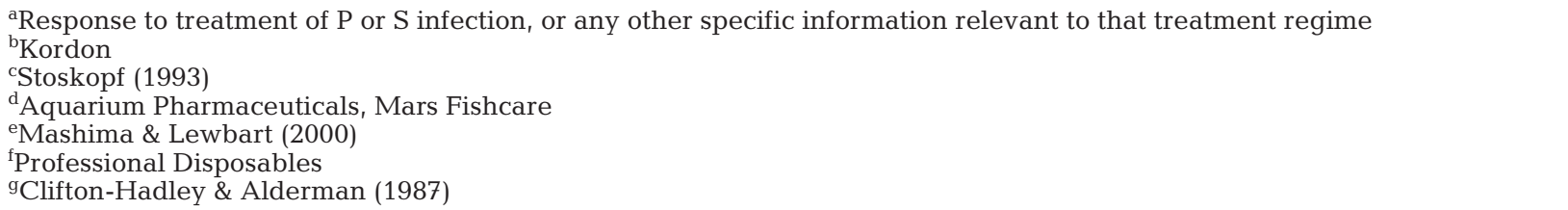 } \\
\hline
\end{tabular}

of infection, density of host species, development of immunity, and efficacy of therapeutants (Reno 1998). Of these, the ability of a pathogen to infect a host, also called the transmission coefficient $(\beta)$, is considered the prime interaction necessary for an epizootic dis-

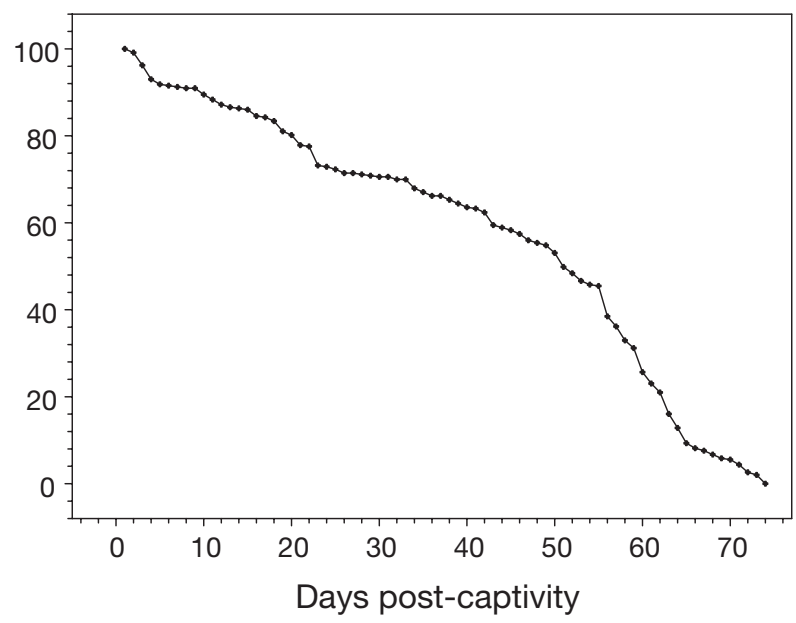

Fig. 3. Channa marulius. Daily survival. Survival was assumed to be $1.0(100 \%)$ on Day 1 (20 June 2008, day of collection) and the first documentation of survival was on Day 2 (21 June 2008) of captivity. A diagnosis of Aphanomyces invadans infection was made at $\sim 60 \mathrm{~d}$ of captivity. Other losses were due to tank-mate aggression, water quality, and desiccation from jumping out of the tanks, but these accounted for $<5 \%$ of the total captive population ease to develop (Reno 1998). To date, no estimates of A. invadans transmission coefficient have been made; however, this epizootic suggests that it can be highly invasive in bullseye snakehead fish. Future investigation into the distribution and prevalence of $A$. invadans within the bullseye snakehead range and surrounding regions in south Florida may help elucidate whether this pathogen plays a role in the distribution of this exotic fish species.

Acknowledgments. We thank P. L. Shafland and the electrofishing crew of the Florida Fish and Wildlife Conservation Commission, Non-native Species Research Laboratory, in Boca Raton, Florida, for collection of and information on juvenile bullseye snakeheads (FWC Permit \# ESC Possession 0814). We also thank the Department of Biology and Research and Sponsored Programs for supporting and funding (Grant \#164053; IACUC \#2008-003) research on bullseye snakehead as well as their transport from south Florida. Finally, we thank the staff of the University of Georgia Veterinary Diagnostic and Investigational Laboratory for help in sample processing, especially D. Rousey, K. Bridges, and M. Gandy. Use of trade or product names does not imply endorsement by the US Government.

\section{LITERATURE CITED}

Blazer VS, Vogelbein WK, Densmore CL, May EB, Lilley JH, Zwerner DE (1999) Aphanomyces as a cause of ulcerative skin lesions of menhaden from Chesapeake Bay tributaries. J Aquat Anim Health 11:340-349 
Blazer VS, Lilley JH, Schill WB, Kiryu Y, Densmore CL, Panyawachira V, Chinabut S (2002) Aphanomyces invadans in Atlantic menhaden along the east coast of the United States. J Aquat Anim Health 14:1-10

Campbell RE, Lilley JH, Taukhid, Panyawachira V, Kanchanakhan S (2001) In vitro screening of novel treatments for Aphanomyces invadans. Aquacult Res 32: $223-233$

Carson FL (1997) Histotechnology: a self-instructional text. American Society for Clinical Pathology Press, Chicago, IL

Chinabut S (1998) Epizootic ulcerative syndrome: information up to 1997. Fish Pathol 33:321-326

Clifton-Hadley RS, Alderman DJ (1987) The effects of malachite green upon proliferative kidney disease. J Fish Dis 10:101-107

Courtenay WR (2007) Introduced species: What species do you have and how do you know? Trans Am Fish Soc 136: $1160-1164$

Courtenay WR, Williams JD (2004) Snakeheads (Pisces, Channidae): a biological synopsis and risk assessment. USGS Circ 1251. US Department of Interior, US Geological Survey, Gainesville, FL

Dykstra MJ, Noga EJ, Levine JF, Moye DW, Hawkins JH (1986) Characterization of the Aphanomyces species involved with ulcerative mycosis in menhaden Brevoortia tyrannus. Mycologia 78:664-672

Dykstra MJ, Levine JF, Noga EJ, Hawkins JH and others (1989) Ulcerative mycosis: a serious menhaden disease of the southeastern coastal fisheries of the United States. J Fish Dis 12:175-178

Fairweather DJ (1999) Development of a bath challenge system to study component causes, and preventative treatments, of epizootic ulcerative syndrome (EUS) in snakehead fish (Channa striata). MS thesis, University of Plymouth

Fuller PL, Nico LG, Williams JD (1999) Nonindigenous fishes introduced into inland waters of the United States. Am Fish Soc Spec Publ 27:477-478

Hartman KH (2006) Fish. In: Baer CK (ed) Guidelines for euthanasia of nondomestic animals. American Association of Zoo Veterinarians, Yulee, FL, p 28-38

Hawke JP, Grooters AM, Camus AC (2003) Ulcerative mycosis caused by Aphanomyces invadans in channel catfish, black bullhead, and bluegill from southeastern Louisiana. J Aquat Anim Health 15:120-127

Johnson RA, Zabrecky J, Kiryu Y, Shields JD (2004) Infection experiments with Aphanomyces invadans in four species of estuarine fish. J Fish Dis 27:287-295

Kattenbelt JA, Hyatt AD, Gould AR (2000) Recovery of ranavirus dsDNA from formalin-fixed archival material.

Editorial responsibility: David Bruno,

Aberdeen, UK
Dis Aquat Org 39:151-154

Kiesecker JM, Blaustein AR, Miller CL (2001) Transfer of a pathogen from fish to amphibians. Conserv Biol 15: $1064-1070$

Kiryu Y, Shields JD, Vogelbein WK, Kator H, Blazer VS (2003) Infectivity and pathogenicity of the oomycete Aphanomyces invadans in Atlantic menhaden Brevoortia tyrannus. Dis Aquat Org 54:135-146

Lilley JH, Roberts RJ (1997) Pathogenicity and culture studies comparing the Aphanomyces involved in epizootic ulcerative syndrome (EUS) with other similar fungi. J Fish Dis 20:135-144

Lilley JH, Callinan RB, Chinabut S, Kanchanakhan S, MacRae IH, Phillips MJ (1998) Epizootic ulcerative syndrome (EUS) technical handbook. Aquatic Animal Health Research Institute, Bangkok

Mashima TY, Lewbart GA (2000) Pet fish formulary. In: Fronfield SA (ed) The veterinary clinics of North America: exotic animal practice therapeutics, Vol 3(1). WB Saunders, Philadelphia, PA, p 117-130

Noga EJ, Wright JF, Levine JF, Dykstra MJ, Hawkins JH (1991) Dermatological diseases affecting fishes of the Tar-Pamlico Estuary, North Carolina. Dis Aquat Org 10: $87-92$

Odenkirk J, Owens S (2005) Northern snakeheads in the tidal Potomac River system. Trans Am Fish Soc 134: 1605-1609

Reno PW (1998) Factors involved in the dissemination of disease in fish populations. J Aquat Anim Health 10: $160-171$

Shafland PL, Gestring KB, Stanford MS (2008) Florida's exotic freshwater fishes - 2007. Fla Sci 7:220-245

Sosa ER, Landsberg JH, Kiryu Y, Stephenson CM and others (2007a) Pathogenicity studies with the fungi Aphanomyces invadans, Achyla bisexualis, and Philaemonium dimorphosporum: induction of skin ulcers in striped mullet. J Aquat Anim Health 19:41-48

Sosa ER, Landsberg JH, Stephenson CM, Forstchen AB, Vandersea MW, Litaker RW (2007b) Aphanomyces invadans and ulcerative mycosis in estuarine and freshwater fish in Florida. J Aquat Anim Health 19:14-26

Stoskopf MK (1993) Appendix V: chemotherapeutics. In: Stoskopf MK (ed) Fish medicine. WB Saunders, Philadelphia, PA, p 832-839

US Geological Survey (2009) US Geological Survey Nonindigenous Aquatic Species database (USGS-NAS). Available online: http://nas.er.usgs.gov

Vandersea MW, Wayne LR, Yonnish B, Sosa E and others (2006) Molecular assays for detecting Aphanomyces invadans in ulcerative mycotic fish lesions. Appl Environ Microbiol 72:1551-1557

Submitted: April 23, 2009; Accepted: September 25, 2009

Proofs received from author(s): January 7, 2010 